\title{
Phylogenetic analysis of ovine herpes virus-2 (OHV-2) in malignant catarrhal fever infected cattle in Al-Qadisiyah governorate of Iraq
}

\author{
Y.I. Khudhair ${ }^{1}$,H.N. Ayyez $^{2}$ and M.H. Hussain ${ }^{1 *}$ \\ ${ }^{1}$ Department of Internal and Preventive Veterinary Medicine, ${ }^{2}$ Zoonosis Unit, College of Veterinary Medicine, University of \\ Al-Qadisiyah, Al-Qadisiyah, Iraq, ${ }^{1}$ Email: yahia.khudiar@qu.edu.iq, ${ }^{2}$ hayder.ayiz@qu.edu.iq, ${ }^{*}$ muthanna.hussain@qu.edu.iq
}

(Received May 7, 2018; Accepted June 4, 2018)

\begin{abstract}
Ovine herpesvirus-2 is a member of the gammaherpesviruses of the herpeseviridae, which is the etiologic agent of malignant catarrhal fever (MCF), a significant fatal disease of cattle. MCF disease was diagnosed in native Iraqi cattle of AlQadisiyah governorate of Iraq, during the period from April 2014 and August 2016. Twenty-three blood samples were collected from clinically suspected cattle. The presence of the virus in samples was ascertained based on clinical pictures, postmortem examination and molecular assays. Pansystemic involvement included respiratory, digestive, urinary, nervous systems and ocular lesions were described. A molecular analysis based on a tegument protein gene by specific semi-nestedPCR, DNA sequence and multiple alignments of all PCR products confirmed the Ovine herpesvirus-2 (OHV-2) infection, and revealed a single and double nucleotide deletion, insertion and substitutions. Some of these mutations were non-silent, resulting in changes at the predicted amino acids level into viral tegument protein. The phylogenetic analysis showed the disease was caused by two genovariants of OHV-2 including at one cluster and were related to other sequences from others countries was analyzed. MCF is sporadically occurring in cattle in Iraq, the head and eye form is more pronounced form. It has been concluded that study is provides valuable information about the genetic variation among the OHV-2 genotypes in Iraqi cattle. Based on sequence and phylogenetic analysis of tegument protein gene, this paper elucidated genetic relationship between identified Iraqi OHV-2 with other strains detected in other geographical regions. These results provide new information on the epidemiological and genetically of OHV-2 in Iraq.
\end{abstract}

Keyword: MCF, Iraq, Ovine herpesvirus-2, genovariants, Al-Qadisiyah governorate, Iraq Available online at http://www.vetmedmosul.com

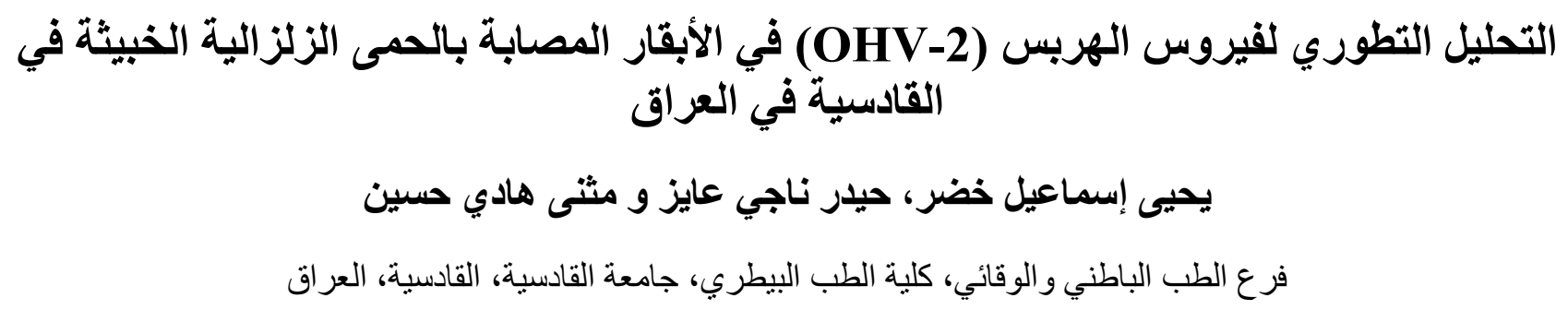

يعد فايروس هربس الأغنام أحد أفراد مجموعة كاما هربس العائدة لعائلة الهربس. مسبب هذ الفيروس مرض فئس الحمى النزلية الخبيثة

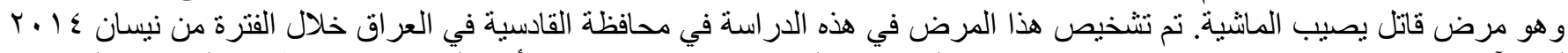

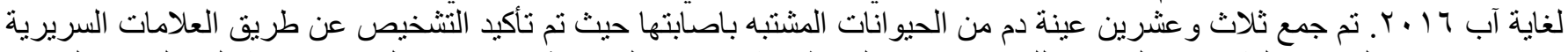

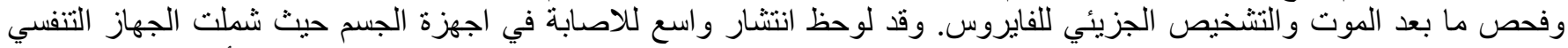

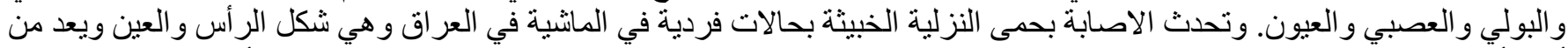

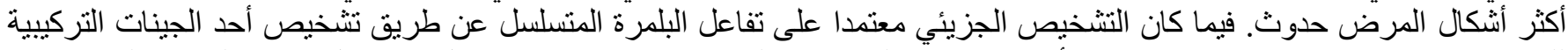

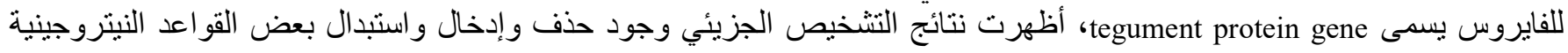




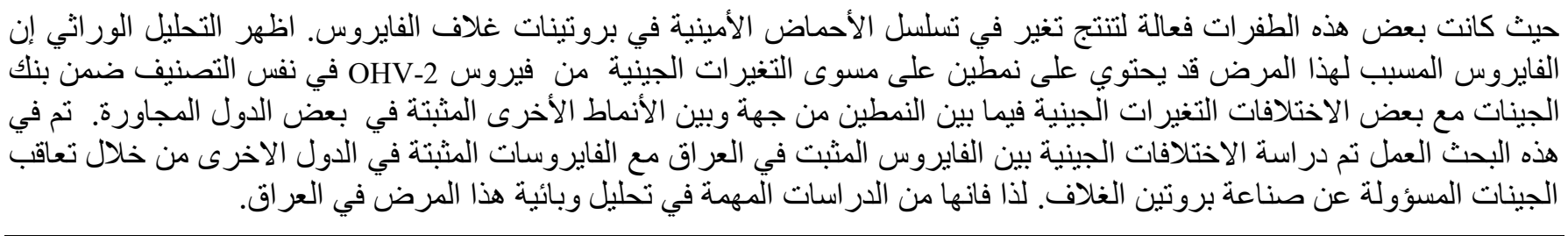

\section{Introduction}

Classical malignant catarrhal fever (MCF) is one of highly serious and fatal infectious disease of many species of the families Bovidae and Cervidae, including cattle, buffaloes, other wild living ruminants and various species of Suidae (1-4). MCF caused by about ten members of the MCF viruses grouped within ruminant gammaherpesviruses of the genus Macavirus (5-7). MCFVs causes a significant economic impact on susceptible hosts $(8,9)$, among these viruses, alcelaphine herpes virus-1 (AlHV-1) and ovine herpesvirus-2 (OvHV-2), are highly related antigenically and genetically and cause the major problem and the ubiquitous prevalent (10). Wildbeest associatedMCF (WA-MCF) can be propagated in vitro and relatively well characterized $(11,1)$. The characterization of sheep association-MCF (SA-MCF) has been restricted because the causative agent has never been successfully propagated in vitro yet $(2,12)$.

The disease forms range from acute severe inflammatory disease with a short clinical course to a more chronic syndrome occasionally with skin form (13). The summarized symptoms of MCF in cattle are marked with high fever, depression, anorexia, conjunctivitis, corneal opacity, lymphadenopathy, ulceration and erosions of the upper digestive and respiratory systems, and neurological disorders, in chronic cases weight loss, muscle atrophy and bilaterally symmetric alopecia $(13,14)$.

Previously, the disease was diagnosed based on the epidemiological and clinicopathological findings (3). Virus neutralizing antibodies generated against one MCFV cross react with other members of the genus (10). The development of the PCR-assay using specific primers, coupled with sequencing has allowed for the identification and classification of some organisms like viruses that have been impossible or difficult to identify using traditional virological methods (15).

Unfortunately, the knowledge about the current situation of MCF infection of cattle in Iraq is absolutely absent. The main objective of this study was to identify the relative causes of MCF like disease and deaths in farmed cattle. The secondly to describe a molecular identified OHV-2 based semi-nested PCR of tegument protein gene-based sequencing and phylogeny analysis.

\section{Material and methods}

\section{Ethics statement}

This study, the owners of the animals gave permission for their animals for examination and necropsy with samples collection.

\section{Animals and sample collections}

Between April 2014 and August 2016, a total of twentythree cattle (15 males 1 to 2 years old and 7 females 8 months to 4 years in except one female calf in 4 months of age) from different parts of Al-Qadisiyah governorate show different clinical signs of MCF like disease. Ten milliliters of EDTA blood sample was collected from each animal, and submitted to the diagnostic laboratory at College of Veterinary Medicine, University of Al-Qadisiyah, Iraq.

\section{Post mortem examinations}

Two animals were slaughtered and necropsied for detection the main pathological changes of disease.

\section{Sample preparation}

Buffy-coat cells from 23 samples were obtained according to (2). $40 \mathrm{ml}$ lysis buffer consist from (10 mM CHKO3, $0.1 \mathrm{mM}$ EDTA, $0.15 \mathrm{M} \mathrm{NH} 4 \mathrm{Cl} \mathrm{pH} 7.2$ ) was added to $10 \mathrm{ml}$ of blood, centrifugation at $8500 \mathrm{~g}$ for 10 min. The supernatants were discarded. This step was repeated 2-3 times. The cells pellet was resuspended with $40 \mathrm{ml}$ phosphate-buffered saline (PBS), then followed by second time centrifugation and discard the supernatant, and stored at $-20 \mathrm{C}$ until use.

\section{DNA extraction}

The viral DNA was extracted from frozen peripheral blood leukocytes (PBL) using the virus DNA/RNA extraction kit (Geneaid, New Taipei City, Taiwan), according to the instructions of the manufacturer.

\section{Semi nested-Polymerase chain reaction (Semi nested - PCR)}

Potential Semi nested - PCR assay specific for amplified the highly variable region of OHV-2 tegument gene. The primer sets 556 - forward, (5'-AGT CTG GGT ATA TGA ATC CAG ATG GCT CTC-3') (121692-121722) and 755 reverse, (5'-AAG ATA AGC ACC AGT TAT GCA TCT GAT AAA-3') (21312-121340) were used in first step for 
amplification of DNA fragments containing $442 \mathrm{bp}$, a second step used $2 \mu 1$ of first PCR product template with the 555- internal reverse (5'TTCTGGGGTAGTGGCGAGCGAAGGCTTC-3')

(121484-121510), with the same forward primer $(16,17)$. The final reaction mixture contained $20 \mathrm{mM}$ Tris $\mathrm{HCl}, \mathrm{pH}$ 8.4, $50 \mathrm{mM} \mathrm{KCl}, 1.5 \mathrm{mM} \mathrm{MgCl}$, $2001 \mathrm{M}$ dNTPs, $10 \mathrm{pM}$ of each primer, $1 \mathrm{U}$ Taq polymerase (IDT, Belgium), and $4 \mu 1$ DNA template. Briefly, Thermal cycling conditions were carried out with initial denaturation at $95^{\circ} \mathrm{C} / 5 \mathrm{~min},(40$ cycles of denaturation $94^{\circ} \mathrm{C} / 2 \mathrm{~min}, 52{ }^{\circ} \mathrm{C} / 45 \mathrm{sec}$. for annealing step, and $72{ }^{\circ} \mathrm{C} / 60 \mathrm{sec}$. for extension), followed by $72{ }^{\circ} \mathrm{C} / 7 \mathrm{~min}$ final elongation, then PCR products were loaded on $1.25 \%$ agarose gel and viewed by a BioRad Gel Doc XR image analysis system.

\section{Sequence Determination and accession numbers}

PCR amplicons were sequenced in both directions with a sequencing kit in an automated sequencer in Macrogen Korea. Sequencing primers were the same first step PCR reaction $(556 \mathrm{~F}$ and $775 \mathrm{R})$ primers mentioned above. The sequencing has been deposited in the EMBL/GenBank/DDBJ databases with accession numbers are KY635410.1 and KY635409.1.

\section{Multiple alignment and Phylogenetic Analysis}

The consensus sequences were assembled from overlapping fragments of DNA was T-coffee Sequence Alignment version 5.0.9 used for editing, alignment, and translation of the nucleotide sequences. Molecular characterization and phylogenetic analysis of local strains have been undertaken as compare with globally published strains from GenBank. A rooted neighbor-joining tree was constructed by using T-coffee (http://tcoffee.crg.cat/apps/tcoffee/index.html). The robustness of the tree topology was assessed with 1,000 bootstrap replicates as implemented in the program. Percentage values are indicated at nodes of the tree, and translated into predicted protein sequences using the APEplasmid editor software.

\section{Results}

\section{Clinical findings}

During 28 months, A total of 20 and 3 animals show severe and relatively mild cases, respectively of MCF were detected until August 2016, all diseased animals was dying after 8 to 20 day were noticed, it exhibits a clinical sign of sever acute to relatively sub-acute (mild) of clinical signs of MCF. The head and eye form was predominant form, keratitis starts from periphery directly to center marked with opacity, sever keratoconjunctivitis, blepharospasm, photophobia, frequently with ocular and bilateral mucopurulent nasal discharge (Figure 1A and B), redness of buccal and nasal mucosa, erosive and necrosis lesions in the mouth papillae especially in chicks and tongue (Figure 2A). Lymph nodes enlargement, high persistent fever (40$41.5^{\circ} \mathrm{C}$ ) were marked signs occasionally with anorexia, digestive system signs seen in 2 males as bloody diarrhea, hematuria revealed in low percentage (one animal). Dullness, shacking of head incoordination and sternal recumbency were a common nervous sign noticed. One adult cow appeared with bilateral corneal opacity with apparent blindness only (Table 1).

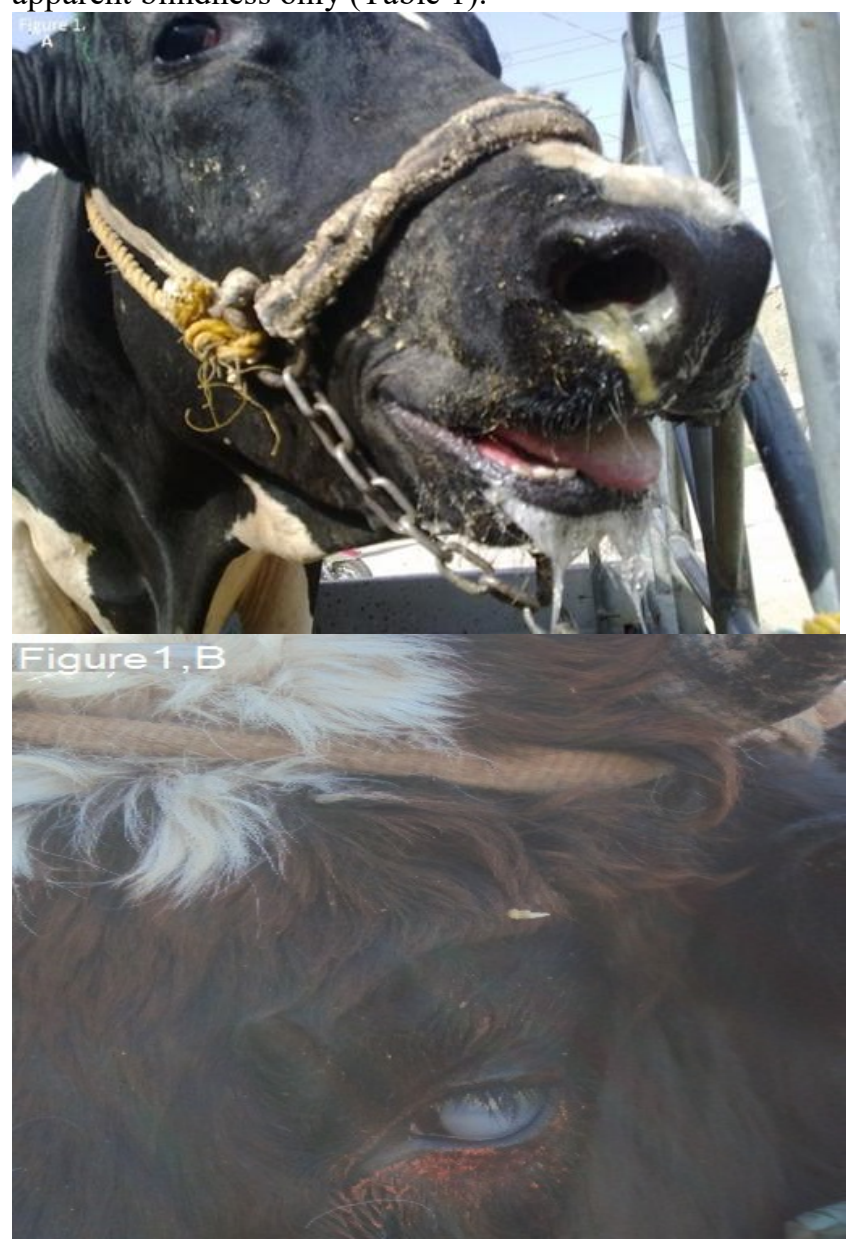

Figure 1: MCF clinical signs and some important necropsy findings: (A) A mucopurulent nasal secretion and ruby (frothy) salivation around mouth of infected animal. (B) Corneal opacity is usually bilateral.

\section{Postmortem examination}

The necropsy finding revealed ulceration, redness of the tongue and buccal papilla, Petechial to ecchymotic hemorrhages were find within serosal and mucosal surfaces of the mesenteric and internal organs, splenomegaly (Figures 3B), there is sever cystitis and the urinary bladder filled with dark red urine. 
Table 1: Clinical manifestations of MCF infected cattle

\begin{tabular}{lc}
\hline Clinical signs & No. of animals \% \\
\hline Fever & $23(100 \%)$ \\
Keratoconjunctivitis (opacity of & $18(78 \%)$ \\
corona) & $2(8.7 \%)$ \\
Bloody diarrhea & $12(52.2 \%)$ \\
Ocular and bilateral mucoprulent & $23(100 \%)$ \\
nasal discharge & $2(8.7 \%)$ \\
Anorexia & $3(13.03 \%)$ \\
Blepharospasm & $5(21.7 \%)$ \\
Blindness & $20(87 \%)$ \\
Erosive and necrosis & $20(87 \%)$ \\
lesions & $5(21.7 \%)$ \\
Lymph nodes & enlargement \\
Dullness & $2(8.7 \%)$ \\
Shacking of head and & $1(4.34 \%)$ \\
incoordination & Sternal recumbency \\
Hematuria & \\
\hline
\end{tabular}

PCR

The DNA was sufficiently extracted from PBL of 23 samples were successfully amplified by semi nested-PCR and yielded visible bands as described above, was identified as the cause of MCF disease in cattle (Figure 4).

Sequence analyses of the $442 \mathrm{bp}$ tegument protein gene fragment. Demonstrated the OHV-2 were group under two distanced clusters have highest nucleotide identity (88.24\%) among them. In fact, relatively differences were observed in the sequences analyzed from the samples belonging to the same geographical area. The nucleotide sequences that obtained in this study were compared with others viral strains from various countries at the GenBank database using the BLAST program, which revealed the identity ranged from $96.04 \%$ to $86.84 \%$ (Table 2). The multiple alignments with deduced amino acids were has been amino acids identity $95.7 \%$ to 90.1 (Figure 5).

The analysis of these sequences revealed OHV-2 in geographical area of study grouped at two distinctive clusters (called Iraqi1 and Iraqi2). The identity among detected virus in this study was $88.24 \%$, a mild number of nucleotide substitutions in both strains, and deletions at Iraqil strain located between were observed in both clusters. And an insertions or frame shift mutations were detected. No other variations like deletions were tack place. The identity between sequences and reference sequences obtained from GenBank database varies from 86.84 to $96.04 \%$.

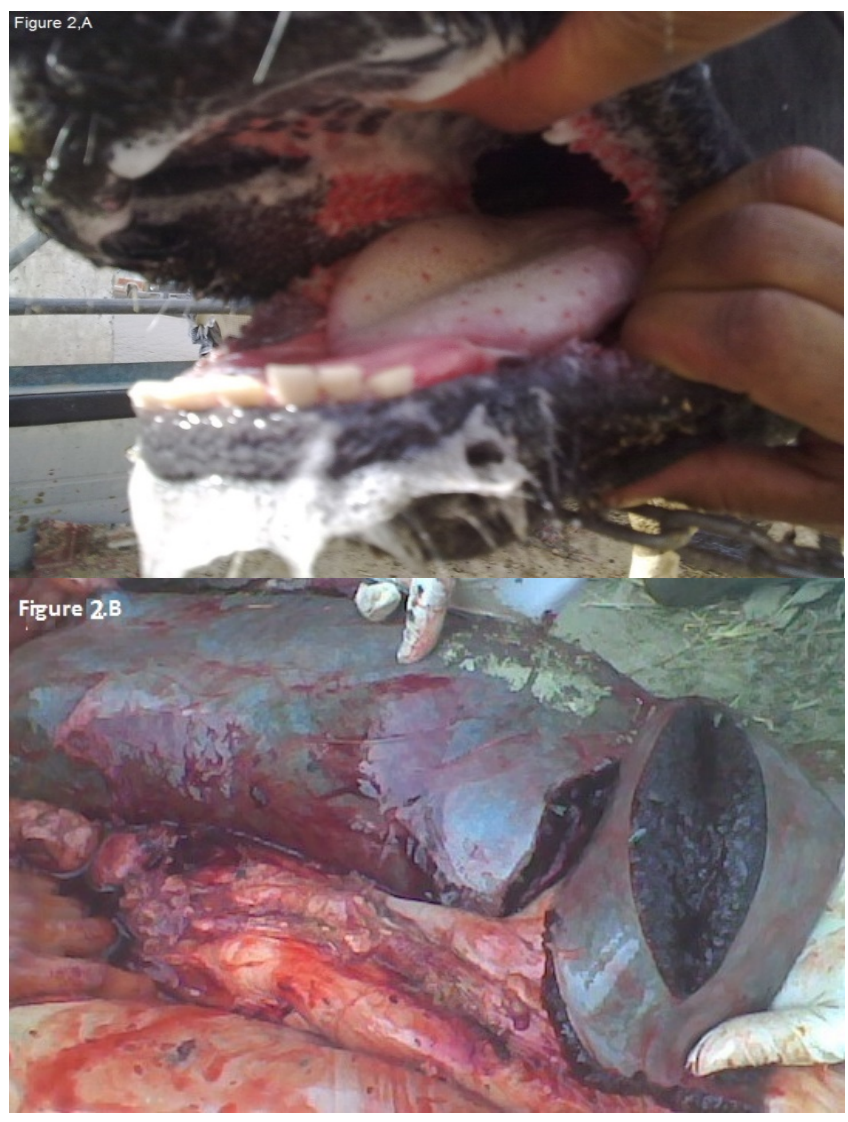

Figure 2: (A) Redness and hemorrhages of tips of papplea of buccal cavity and tongue. (B) Splenomegaly of MCF infected cattle with sever congestion.

Table 2: demonstrate the nucleotides identities and predicted amino acids identities of partial sequence of tegument protein gene among Iraqi strains and between them and others published references

\begin{tabular}{lcccc}
\hline \multirow{2}{*}{ Strains } & \multicolumn{2}{c}{$\begin{array}{c}\text { Nucleotide } \\
\text { alignment }\end{array}$} & \multicolumn{2}{c}{$\begin{array}{c}\text { Deduced amino } \\
\text { acid alignment }\end{array}$} \\
\cline { 2 - 5 } & Iraq2 & Iraq1 & Iraq2 & Iraq1 \\
\hline Iraq2 & & 88.24 & & 90.64 \\
Iraq1 & 88.24 & & 90.64 & \\
Canada & 86.84 & 90.10 & 90.35 & 90.07 \\
Brazil & 92.11 & 95.05 & 94.74 & 95.36 \\
India & 92.11 & 96.04 & 94.74 & 95.36 \\
Egypt & 92.11 & 96.04 & 92.63 & 92.12 \\
Germany & 92.11 & 96.04 & 93.86 & 95.36 \\
South Africa & 92.11 & 95.70 & 94.30 & 95.70 \\
Turkey & 90.48 & 92.73 & 93.23 & 92.81 \\
Magnolia & 90.48 & 92.73 & 93.23 & 92.81 \\
Italy & 90.48 & 92.73 & 93.86 & 95.70 \\
United state & 88.89 & 91.30 & 93.19 & 92.77 \\
\hline
\end{tabular}




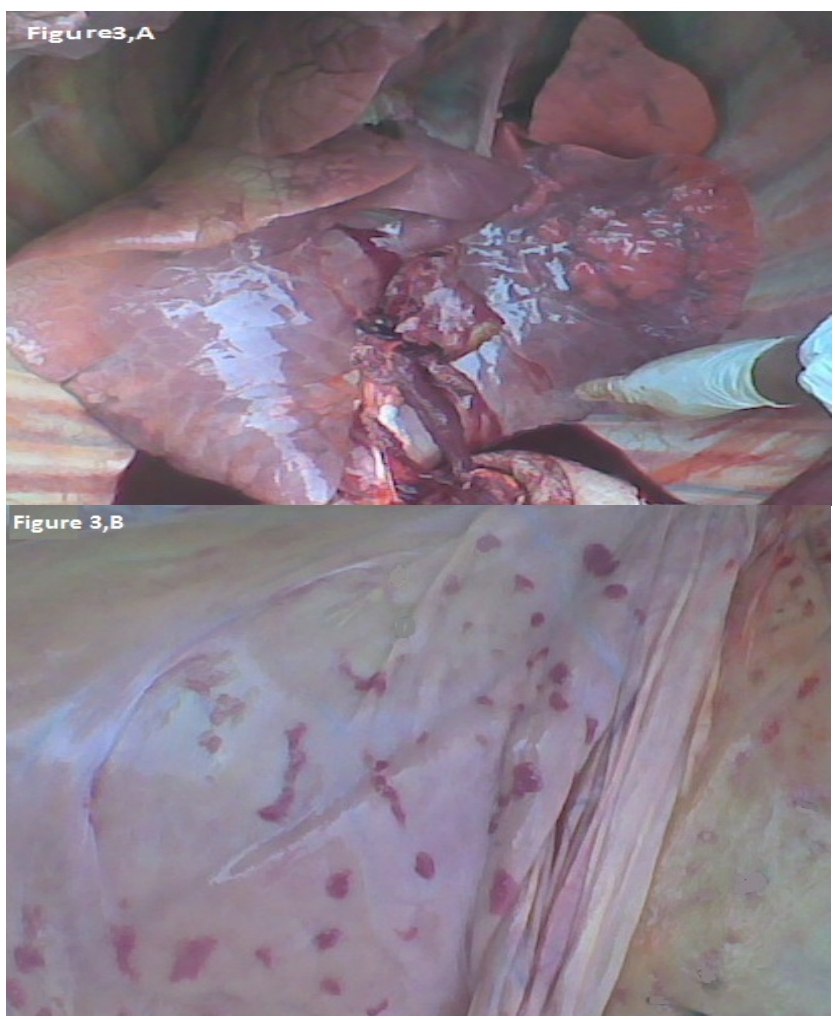

Figure 3: (A) petechial and ecchymotic hemorrhages of omentum and serosa of abomasum of the right ocular globe fibrinopurulent bronchopneumonia, (B) petechial hemorrhages within the mesenteric, thoracic and pleural surfaces, ulcerative stomatitis and rhinitis, pulmonary edema, lymphadenomegaly and bilateral multifocal hemorrhagic.

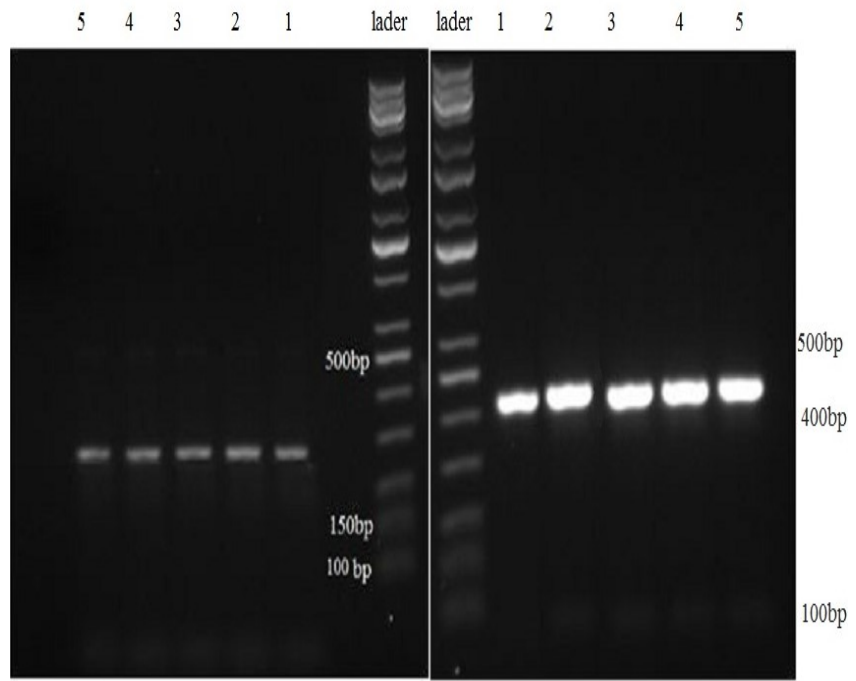

Figure 4: PCR amplicons obtained with OHV-2 specific primers from the PBL of MCF like disease infected cattle. Lane Ladder, molecular size markers; Lanes (1 to 5) represent the five Agarose gel electrophoresis of ethidium bromide-stained PCR products amplified from different DNA samples with primers specific for OHV-2 (A) first step PCR of OHV-2 DNA of tegument protein gene, the $422 \mathrm{bp}$ corresponding to ladder (B) second step of semi nested- PCR for the OHV-2 of the same gene shows $223 \mathrm{bp}$.

\begin{tabular}{|c|c|}
\hline Iraq1 & SSPSIMLTPL ARMVLPCWVRG---KYLGLSYSADGVEHSLFQTNTVA \\
\hline Iraq2 & SSPSIMLTPCRGMVLPCWVRGANTWGRCYSADGVEHSLFQTNTVA \\
\hline Eygpt & SSPSIMLTPCRGMVLPCWVQG---KYLGLSYSADGVEHSLFQTNTVA \\
\hline Germany & SSPSIMLTPCRGMVLPCWVQG---KYLGLSYSADGVEHSLFQTNTVA \\
\hline Brazil & SSPSIMLTPCRGMVLPCWVQG---TYLGLSYSADGVEHSLFQTNTVA \\
\hline South & SSPSIMLTPCRGMVLPCWVQG---KYLGLSYSADGVEHSLFQTNTVA \\
\hline Canada & SSPSLMLTPCRGMVLPCWVQG--TYLGLSYKADGVEHNLFQTNTVA \\
\hline Turkey & SSPSIMLTPCRGMVLPCWVQG---KYLGLSYSADGVEHSLFQTNTVA \\
\hline Mangolia & SSPSIMLTPCRGMVLPCWVQG---KYLGLSYSADGVEHSLFQTNTVA \\
\hline Italy & SSPSIMLTPCRGMVLPCWVQG---KYLGLSYSADGVEHSLFQTNTVA \\
\hline U.S. & SSPSIMLTPCRGMVLPCWVQG---KYLGLSYSADGVEHSLFQTNTVA \\
\hline India & SSPSIMLTPCRGMVLPCWVQG---KYLGLSYSADGVEHSLFQTNTVA \\
\hline
\end{tabular}

Figure 5: Alignment of predicted amino acid sequences from the OHV-2 DNA tegument protein PCR from MCF infected Iraqi cattle, with ten known MCF viruses. unsimilar residues between aligned sequences for a given position are colored (green). The additional residue (asparagine) colored (red)in iraq2 strain, Identity between the OHV-2 predicted amino acid sequence and other OHV-2 viruses from various countries is shown in bold adjacent to the ends of the sequences. GenBank numbers (and references) for Canada, Brazil, India, Egypt, Germany, South Africa, Turkey, Magnolia, Italy and United states, KJ705001.1_USA, KX060582.1, KJ658293.1, HM216475.1, KJ420947.1, JX442930.1, KP015737.1, LC203437.1, JN084009.1, HM216481.1, JN084011.1 respectively. 
All OHV-2 tegument protein sequences were with mild diversity. The similarity ranged between 95.7 and $86.84 \%$ at the nucleotide sequence level and between 95.7 and $90.35 \%$ at the deduced amino acid sequence level. Iraq2 strain have three nucleotide bases for coding additional residue of asparagine which are located at 163-165 position of tegument protein gene of one of Iraqi strains, and two amino acid substitutions.

Sequences and phylogenetic analyses of nucleotides and protein of tegument protein gene showed that the strains from Iraq had some diversity from each other by $95 \%$ and $94 \%$ respectively, diverging by 10 out of the 309 nucleotides and 9 diverging out of 105 amino acids analyzed (Figure 6).

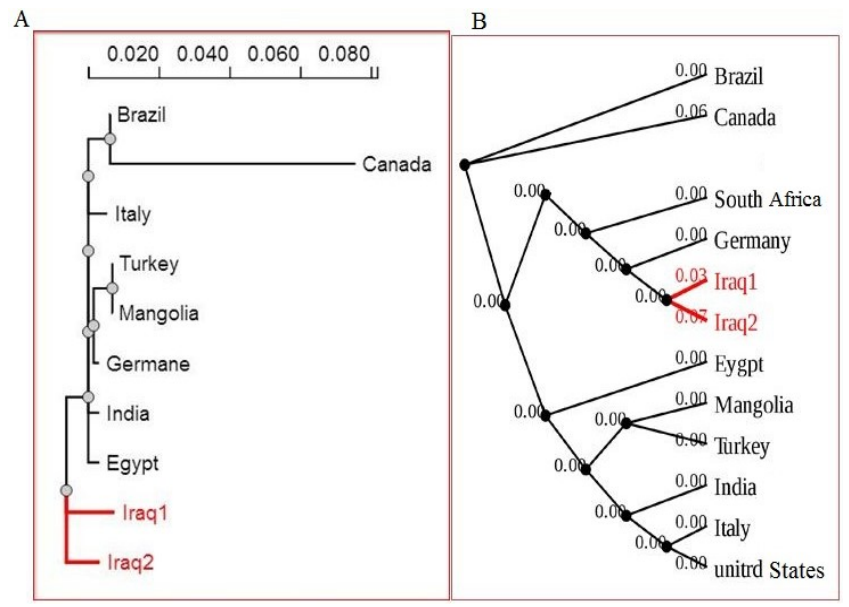

Figure 6: Phylogenetic trees for the DNA tegument protein gene of OHV-2 obtained from SA-MCF of Iraqi cattle. (A) The rooted tree of nucleotides alignment was generated using the distance matrix program $\mathrm{T}$ coffee with the jumble option evoked. (B) The rooted tree of predicted amino acids alignment was generated using the distance matrix program $\mathrm{T}$ coffee with the jumble option evoked. Distance values were calculated using the PROTDIST program with the Dayhoff percent accepted mutation matrix. Bootstrap values of greater than 50 are shown, and the branch lengths represent relative genetic distances. The herpesviruses used for comparison and their accession numbers are as follows for Canada, Brazil, India, Egypt, Germany, South Africa, Turkey, Magnolia, Italy and United states, KJ705001.1_USA, KX060582.1， KJ658293.1, HM216475.1， KJ420947.1， JX442930.1， KP015737.1， LC203437.1， JN084009.1， HM216481.1， JN084011.1 respectively.

\section{Discussion}

In Iraq, despite the clinically presence of $\mathrm{MCF}$, there is no any study concerning with cases of the disease in cattle, therefore the evaluation of suspected MCF cases by clinical and molecular methods for detect the causes of the disease which was likely to have contributed directly to the death of cattle in Iraq, so this study is the first report has established the presence of the disease in native cattle of the country. And the use of a diagnostic assay directly targeting a viral component would be of great relevance to confirm the diagnosis (18).

The major clinical signs observed wide fluctuation in severity, almost presence head and eye form and other forms were similar to previous reports of MCF in cattle and other domestic and wild ruminants like buffaloes, bison and deer (19-22). Some cases were no developing the erosive or ulcerative lesions in mouth and oral cavity, these results were agreeing with (23). Animals represent with corneal opacity, blandness and anorexia were also noted by (24).

Although the results of necropsy finding that reported here were similar to MCF, corneal edema, acute ulcerative end erosive omasitis and abomasitis, petechial or ecchymotic hemorrhages in mucosal and serosal surfaces of internal organs, pericardial and pericardial hemorrhages, edematous lymph nodes were finding in cattle and buffalo (20).

Analyses of genetic variation of OHV-2 obtained from clinical case samples by looking at important region to address the hypothesis that the highly polymorphic tegument protein gene is a useful epidemiological marker of OHV-2 strain variation, in addition, the use of highly specific primers for conserved regions of viral DNA that flanked the variable region is useful to differentiate among MCF causative members $(22,25)$. These primers have been used previously for detection of OHV-2 DNA $(16,17,26,27)$.

Amplification of the segment of tegument protein gene was attempted in DNA samples from 23 cattle with MCF sporadic presentations were yielded a clear single band of the expected size for each reaction this agreement with $(16,24)$. Others members of the MCFVs are currently detected by the presence of the tegument protein gene (22).

The novel OHV-2- genotypes were identified as the etiology of disease in the Iraqi cattle, and the broad spectrum of clinical signs that may relate to these polymorphisms of virus. This data indicated that the virus present in cattle has some diversity compared to reference OHV-2. The nucleotide identity was similar to previous study of (18) which finds that the sequence identity ranged from 90.9 to $100 \%$ by used the same sets of primers.

The results of the partial sequence comparisons and phylogenetic analysis revealed that the strains of OVH-2 circulating within Al-Qadisiyah governorate is at least two new sub genotypes, these some differed from each other genetically by several nucleotides, these differences based a tegument protein gene we analyzed, with four nucleotide substitutions, four nucleotide deletions in Iraq1 strain and 
three additions in Iraq2 strain, like this genetic diversity were detected (26). Nevertheless, these Iraqi OVH-2 tegument protein gene sequences derived from cattle are $95.5 \%-88.83 \%$ homologous to those derived from cattle in other geographical regions.

The asymptomatic sheep and goat (OHV-2) detected in healthy sheep and goat (unpublished study) would have been the most likely source of infections. In other hand, samples (blood and nasal swabs) were collected from other species of domestic animals. Furthermore, that, the most infections occur by close contact between the carrier animals and susceptible host (26). Several authors reported the transmission of OHV-2 has been occurred when cattle have been separated at least $70 \mathrm{~m}$ to $5 \mathrm{~km}$ from a lamb $(26,28,29)$.

The phylogenetic analysis and the genetic identity among Iraqi genotypes and with those from other countries showed some genomic differences, suggesting that the OHV-2 diagnosed in Iraqi cattle was genetically differ from that found in other regions of the world.

By sequencing the tegument protein gene of the OHV-2 isolates, it showed that the isolates were in the clade with the unidentified strains from Germany and Egypt as well as with the OHV-2 from India. Depend on predicted protein sequence comparisons (105 amino acids) of OHV-2 revealed that the strain Iraq2 differed clearly from all known OHV-2 strains detected in cattle but shared 95\% similarity with the strains obtained from Germany, Italy and Egypt.

\section{Conclusions}

This study considerate a first report about occurrence of MCF in Iraq, and there are at least two different genetic variants of OHV-2 clustered in one group responsible of disease occurrence in Iraq.

\section{References}

1. Wambua L, Wambua PN, Ramogo AM, Mijele D, Otiende MY. Wildebeest-associated malignant catarrhal fever: perspectives for integrated control of a lymphoproliferative disease of cattle in subSaharan Africa. Arch Virol. 2016;161:1-10.

2. Stahel AB, Baggenstos R, Engels M, Friess M, Ackermann M. Two different macaviruses, ovine herpesvirus- 2 and caprine herpesvirus-2, behave differently in water buffaloes than in cattle or in their respective reservoir species. PloS One. 2013;8(12):e83695.

3. Damayanti R. Malignant Catarrhal Fever in Indonesia and Its Control Strategy. WARTAZOA. Indonesian Bul Anim Vet Sci. 2017;26(3):103-114.

4. Amoroso MG, Galiero G, Fusco G. Genetic characterization of ovine herpesvirus 2 strains involved in water buffaloes malignant catarrhal fever outbreaks in southern Italy. Vet Microbiol. 2017;199:31-35.

5. Li H, Cunha CW, Taus NS, Knowles DP. Malignant catarrhal fever: inching toward understanding. Annu Rev Anim Biosci. 2014;2(1):209-233.
6. Davison AJ, Eberle R, Ehlers B, Hayward GS, McGeoch DJ, Minson AC, Thiry E. The order herpesvirales. Arch Virol. 2009;154(1):171177.

7. O'Toole $\mathrm{D}$, Li H. The pathology of malignant catarrhal fever, with an emphasis on ovine herpesvirus 2. Vet Pathol. 2014;51(2):437-452.

8. Li H, Cunha CW, Taus NS. Malignant Catarrhal fever: understanding molecular diagnostics in context of epidemiology. Inter J Mol Sci. 2011;12(10):6881-6893.

9. Lankester F, Lugelo A, Kazwala R, Keyyu J, Cleaveland S, Yoder J. The economic impact of malignant catarrhal fever on pastoralist livelihoods. PloS One. 2015;10(1):e0116059.

10. Taus NS, Cunha CW, Marquard J, O'Toole D, Li H. Cross-reactivity of neutralizing antibodies among malignant catarrhal fever viruses. PloS One. 2015;10(12):e0145073.

11. Berezowski JA, Appleyard GD, Crawford TB, Haigh J, Li H, Middleton DM, Woodbury M. An outbreak of sheep-associated malignant catarrhal fever in bison (Bison bison) after exposure to sheep at a public auction sale. J Vet Dig Invest. 2005;17(1):55-58.

12. Li H, Cunha CW, O'Toole D, Nicola AV, Knowles DP, Taus NS. Development of an in vivo system to measure antibody-blocking of ovine herpesvirus 2 entry. J Virol Meth. 2013;188(1):104-107.

13. Slater OM, Peters KJ, Lejeune M, Gummer D, Macbeth B, Warren A, Duignan PJ. Sheep-Associated Malignant Catarrhal Fever-Like Skin Disease in a Free-Ranging Bighorn Sheep (Ovis canadensis), Alberta, Canada. J Wildlife Dis. 2017;53(1):153-158.

14. Çitil M, Uzlu E. Determination of some oxidative stress and inflammation markers in serum, blood and CSF in cattle with headeye form of malignant catarrhal fever. J Faculty Vet Med Kafkas Uni. 2017;23(4):515-512.

15. Müller UU, Egli J, Hauser B, Li H, Strasser M, Ehrensperger F, Ackermann M. Malignant catarrhal fever in Switzerland: 2. Evaluation of the diagnosis. Schweiz Arch Tierheilkd. 2001;143(12):581-591

16. Baxter SI, Pow I, Bridgen A, Reid HW. PCR detection of the sheepassociated agent of malignant catarrhal fever. Arch Virol. 1993;132:145-159.

17. Li H, Shen DT, Davis WC, Knowles DP, Gorham JR, Crawford T B. Identification and characterization of the major proteins of malignant catarrhal fever virus. J Gen Virol. 1995;76(1):123-129.

18. De SN Martins M, de Castro AM, Lima MD, da SC Pinto V, da Silva TG, Del Fava C, Pituco EM. Malignant Catarrhal Fever in Brazilian cattle presenting with neurological syndrome. Brazilian J Microbiol. 2017;48(2):366-372.

19. Klieforth R, Maalouf G, Stalis I, Terio K, Janssen D, Schrenzel M. Malignant Catarrhal Fever-Like Disease in Barbary Red Deer (Cervus elaphus barbarus) Naturally Infected with a Virus Resembling Alcelaphine Herpesvirus 2. J Clin Microbiol. 2002;40(9):3381-3390.

20. Teankam K, Tantilertcharoen R, Boonserm T, Suadsong S, Banlunara W. Malignant catarrhal fever in swamp buffaloes (Bubalus bubalis): A retrospective pathological study of outbreaks in Thailand. Thai J Vet Med. 2006;36(1):19-30.

21. Taus NS, O'Toole D, Herndon DR, Cunha CW, Warg JV, Seal BS, Li H. Malignant catarrhal fever in American bison (Bison bison) experimentally infected with alcelaphine herpesvirus 2 . Veterinary microbiology. 2014;172(1):318-322.

22. Modesto P, Grattarola C, Biolatti C, Varello K, Casalone C, Mandola ML, Decaro N. First report of malignant catarrhal fever in a captive pudu (Pudu puda). Res Vet Sci. 2015;99:212-214.

23. Orbell G. Malignant catarrhal fever. Vet Script. 2012;27-28

24. Headley SA, Pimentel LA, Oliveira VHS, Toma HS, Alfieri AF, Carvalho AM, Alfieri AA. Transplacental transmission of ovine herpesvirus 2 in cattle with sheep-associated malignant catarrhal fever. J Com Pathol. 2015;153(4):206-211.

25. Starič J, Ježek J, Cociancich V, Gombač M, Hostnik P, Toplak I. Malignant catarrhal fever in American bison (Bison bison) in slovenia. Slovenian Vet Res. 2015;52(4):1. 
26. Sood R, Khandia R, Bhatia S, Hemadri D, Kumar M, Patil SS, Kulkarni DD. Detection and molecular characterization of naturally transmitted sheep associated malignant catarrhal fever in cattle in India. Trop Anim Heal Prod. 2014;46(6);1037-1043.

27. Dettwiler M, Stahel A, Krüger S, Gerspach C, Braun U, Engels M, Hilbe M. A possible case of caprine-associated malignant catarrhal fever in a domestic water buffalo (Bubalus bubalis) in Switzerland. BMC Vet Res. 2011;7(1):78.
28. Headley SA, Sousa IK, Minervino AH, Barros IO, Barrêto RA, Alfieri AF, Alfieri AA. Molecular confirmation of ovine herpesvirus 2induced malignant catarrhal fever lesions in cattle from Rio Grande do Norte, Brazil. Pesq Vet Bras. 2012;32(12):1213-1218.

29. Giangaspero M, Savini G, Osawa T, Harasawa R. Serological survey to determine the occurrence of malignant catarrhal fever infection in the Japanese small ruminant population from northern districts. J Vet Med Sci. 2013;75(6):815-818. 